\title{
Lodhi 5 Properties Investments CC v FirstRand Bank Limited [2015] 3 All SA 32 (SCA) and the Enforcement of Islamic Banking Law in South Africa
}

\section{P.E.R}

Pioneer in peer-reviewed, open access online law publications.

Author

Maphuti David Tuba

Affiliation

University of South Africa, South Africa

Email tubamd@unisa.ac.za

Date published

14 March 2017

Editor Dr A Gildenhuys

How to cite this article

Tuba MD " Lodhi 5 Properties Investments CC v FirstRand Bank Limited [2015] 3 All SA 32 (SCA) and the Enforcement of Islamic Banking Law in South Africa" PER / PELJ 2017(20) -

DOI

http://dx.doi.org/10.17159/17273781/2017/v20i0a1308

Copyright

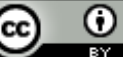

DOI

http://dx.doi.org/10.17159/17273781/2017/v20i0a1308

\begin{abstract}
On 22 May 2015, the Supreme Court of Appeal (SCA) handed down a judgment in the matter of Lodhi 5 Properties Investments CC v FirstRand Bank Limited [2015] 3 All SA 32 (SCA). This judgement considered whether the prohibition against the charging of interest on a loan in terms of Islamic law (Sharia law) may be a defence for a claim for mora interest in terms of a loan agreement. This note critically discusses the judgment in the light of the approach adopted by the SCA with regard to addressing a dispute arising from a contract that has Islamic law as a governing law. As this is the first case to come before the SCA in South Africa, this note critically analyses how the court discussed the principles of Islamic law as applicable to the dispute between the parties. In particular, it questions the court's assertion that a claim for mora interest has nothing to do with and is not affected by the Sharia law's prohibition against payment of interest on a loan debt. It also looks at the SCA's approach (as a common law court) with regard to the enforcement of the principles of Islamic banking law. The judgment raises important issues regarding the enforceability of Islamic finance law and therefore merits discussion in the context of the continuing growth and expansion of Islamic banking and finance law in South Africa.
\end{abstract}

\section{Keywords}

Islamic law; mora interest; riba; Hiyal; profit-and-loss sharing; Sharia; Islam. 


\section{Introduction}

An increase in the number of Muslims worldwide has been observed for many decades. It signals the needed for the non-Islamic world to take cognisance of Islamic law (also known as Sharia law) and practices. This has created a demand for pertinent financial transactions and services to comply with Islamic law. As a result, conflicts of law often arise where the principles of Islamic law are incorporated into the terms of financial agreements concluded in a secular context. Judicial officers in non-Muslim jurisdictions face challenges in terms of how to apply and enforce agreements incorporating these principles. This is particularly so with regard to disputes brought before secular courts in common law (and civil law) jurisdictions such as South Africa, where these courts are often called to interpret and apply, or at least to take cognisance of Islamic law. In 2015 the Supreme Court of Appeal (SCA) was faced with a problem of this kind in Lodhi 5 Properties Investments CC v FirstRand Bank Limited. ${ }^{1}$ This case illustrates the challenges that secular courts encounter when they are confronted with the interpretation and application of uncodified Sharia law, which has been the subject of various scholarly interpretations. It also illustrates the challenges encountered by common law courts with no expertise to interpret and enforce transactions which are subject to Sharia law. This lack of expertise is evident in the abovementioned case, as the courts - both the High Court ${ }^{2}(\mathrm{HC})$ and the SCA - did not address several issues which called for the interpretation of the relevant Islamic finance principles, and thus left more questions unanswered than those that were successfully addressed. The case raises important issues regarding the enforceability of Islamic finance law and merits discussion in the light of the continuing growth and expansion of Islamic banking and finance law in South Africa. The purpose of this case note is to critically analyse the decision in Lodhi 5 SCA in order to determine whether or not the court correctly applied the relevant principles of Sharia law with regard to the prohibition on the charging of riba interest. While the focus of this note is on the decision of the SCA, reference is made to the decision in the $\mathrm{HC}$ in order to illustrate the general approach of South African courts to the interpretation and enforcement of Islamic finance law. The discussion of the case note begins with a brief explication of the fundamental principles of

* Maphuti David Tuba. LLB (WITS) LLM (UNISA). Senior lecturer, Department of Mercantile Law, University of South Africa. Email: tubamd@unisa.ac.za.

$1 \quad$ Lodhi 5 Properties Investments CC v First Rand Bank Limited 20153 All SA 32 (SCA) (hereinafter "Lodhi SCA").

2 FirstRand Bank Ltd v Lodhi 5 Properties Investment CC 20133 SA 212 (GNP) (hereinafter "Lodhi $\mathrm{HC} "$ ). 
Islamic banking law in order to establish the concepts applicable to the case under discussion. This is followed by a description of the facts of the case and the decisions of the $\mathrm{HC}$ and, most importantly, the SCA. A critical analysis of the SCA decision follows thereafter, and then concluding remarks are made on the decision of the SCA.

\section{Fundamental principles of Islamic banking law}

Islamic law is a legal system which is derived primarily from the Quran (the Muslim holy book) and the Sunnah (examples of the practices of Prophet Mohammed). ${ }^{3}$ In terms of Islamic law conduct is either permitted (halaal) or strictly prohibited (haram). ${ }^{4}$ The question as to whether something is permitted or prohibited is not a simple one, however. Engaging in the following financial practices is prohibited in terms of Islamic law: gharar (indulging in risk or uncertainty), maysir (gambling), unjustified enrichment, and riba (charging interest, or usury). ${ }^{5}$ The focus of this note will be on riba, which forms the basis for distinguishing Islamic finance from its conventional counterpart.

\subsection{Riba and the charging of interest on loans}

Islamic law generally regards the charging of interest on loans as oppressive and exploitative, and it is therefore prohibited. ${ }^{6}$ Similar prohibitions on usurious interest exist in conventional banking, with the result that the distinction between interest and riba is sometimes blurred. Unlike the limited prohibition on the charging of interest found in the Bible, ${ }^{7}$ the Quran expresses the prohibition against riba emphatically in four verses. ${ }^{8}$ For instance, the Quran is translated as saying: "O ye who believe! devour not Riba doubled and multiplied". ${ }^{9}$ However, it does not define what the term riba actually means. Riba literally means simply "increase, addition, expansion or growth", ${ }^{10}$ but in the context of financial transactions it means much more than that. Terms such as "effortless gain" and "profit which is given without giving anything in exchange" come to mind. ${ }^{11}$ Sharia law prohibits riba in the sense of the accumulation of wealth that is not a product

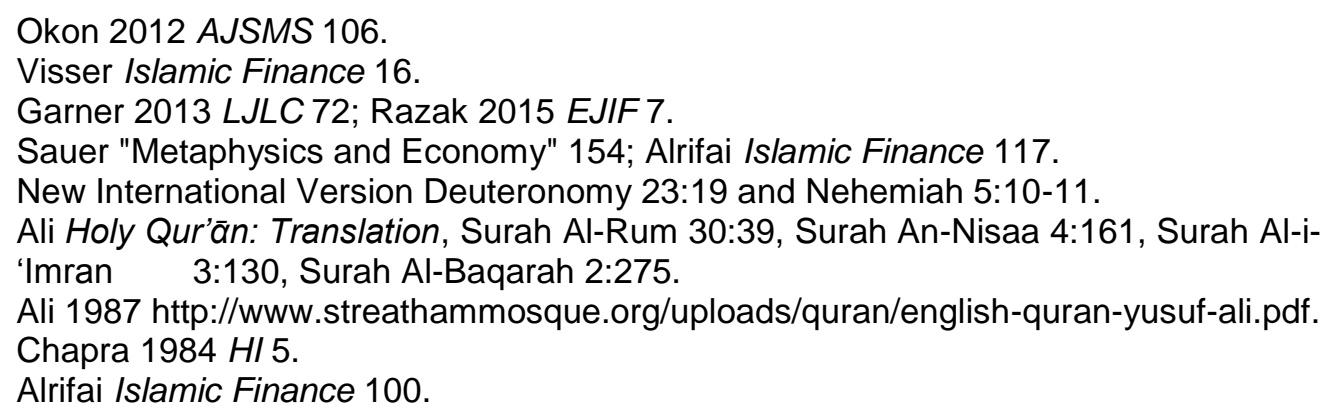


of labour or equivalent financial value. ${ }^{12} \mathrm{~A}$ consensus among Muslim jurists exists that riba has the same literal meaning and import as interest. ${ }^{13}$ It is also agreed that it refers to some form of "premium" that must be paid to the creditor, along with the principal amount, as a condition for extending the loan, or for an extension of its maturity. ${ }^{14}$ Any positive, fixed, or predetermined interest rate that is tied to the maturity of the loan is considered as riba and is therefore prohibited. ${ }^{15}$ Muslim scholars, however, have not reached a consensus on the ambit of the prohibition against riba. This has sparked a conflict of interpretation between the two main categories of Muslim scholars. ${ }^{16} \mathrm{~A}$ tug-of-war on the ambit of riba exists between classical and modern scholars.

The classical Muslim school follows the traditional definition of riba as any additional charge for borrowed money. ${ }^{17}$ They adopt the technical Arabic meaning of riba, which is translated as "an excess" or "increment". ${ }^{18}$ In their view, any additional amount charged over and above the capital originally advanced as a loan is simply "an act of renting money at a price called interest" and is therefore prohibited. ${ }^{19}$ They refute any argument that strives to make a distinction between simple interest (which is not prohibited) and usurious interest (i.e. an exorbitant amount of interest). ${ }^{20}$ According to the classical scholars, any benefit or increase (nominal or real), or any predetermined return on the loan capital advanced is riba and therefore prohibited. ${ }^{21}$ Consequently, any sum added to the principal from an exchange that is not reciprocated by an equivalent of value in return is riba. ${ }^{22}$ Their verdict is that the prohibition against interest is absolute, unambiguous and unconditional. ${ }^{23}$

Modern scholars are, so to speak, "attempting to separate the chaff from the grain". The crux of their debate is about whether riba means interest or usury. ${ }^{24}$ If riba is defined as interest, any commercial transaction which requires the repayment of an amount additional to the capital is invalid under

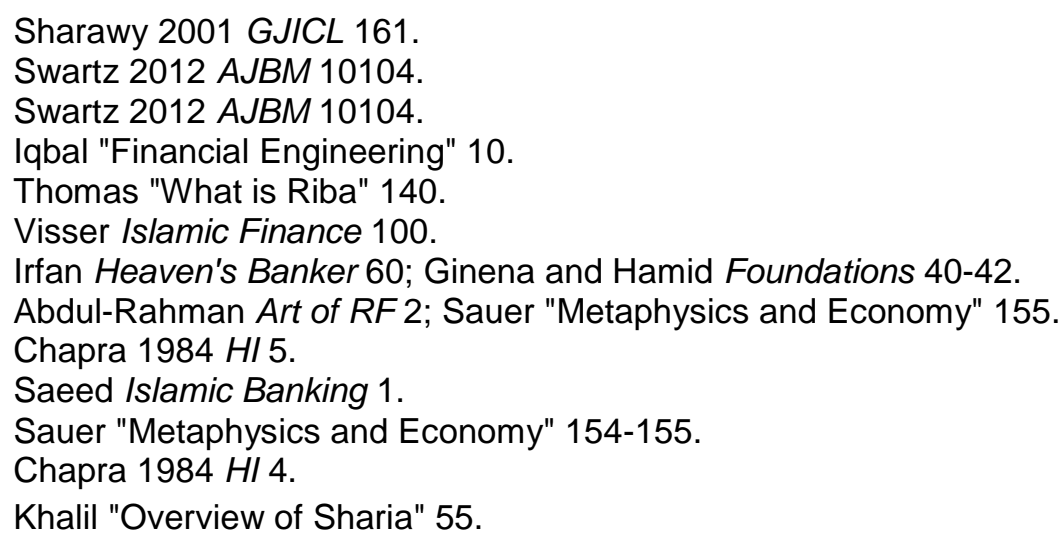


Sharia law. However, if riba simply means usury, as long as the rate of interest has not hit some rate which is determined to be exorbitant, it is valid. ${ }^{25}$ They begin by questioning a ban on riba in the modern-day economy. ${ }^{26}$ Their argument is that riba, as manifested in the Quran, is a very specific form of interest. Riba and interest are two different things, and the ban cannot therefore be applied to all forms of interest found in modern economies. ${ }^{27}$ They argue that the Quran verse quoted above is qualified by its reference to a specific amount of usury. ${ }^{28}$ In their view, the words "doubled or multiplied" connote that "interest is classified as riba if the principal repayable is double the original amount". ${ }^{29}$ What is banned by Sharia law, in their view, is "an unjustified increase" of return on a capital amount. ${ }^{30}$ Their view of the ban on riba in the Quran and Sunnah is different from that of the classical scholars. Rather than defining it literally, they look at the rationale for the injunction as a ban on exploitative forms of interest which have the effect of committing economic injustices against the poor, contrary to Sharia law. ${ }^{31}$ They support their position by arguing that the ban on riba is a ban on usuriously high and excessive interest, which is not equated with interest per se. ${ }^{32}$ Unlike the classical scholars, in their view the ban on interest is conditional and not absolute. ${ }^{33}$ Notwithstanding their different views on riba, there is a consensus amongst Muslim scholars that Sharia law prohibits riba. ${ }^{34}$ They differ only in terms of what qualifies as prohibited riba, and not necessarily on whether or not Sharia law prohibits it. 35

Alongside the prohibition on riba, as argued by the classical scholars, Islamic law also prohibits the additional penalty interest imposed on defaulting customers who fail to meet their obligations. ${ }^{36}$ Any additional amount claimed after the contract is agreed upon (such as an increase in price, default interest levied for late payment, and an early payment penalty) is also unlawful and prohibited as riba. ${ }^{37}$ According to contemporary Muslims, however, Sharia law allows a claim for compensation arising from

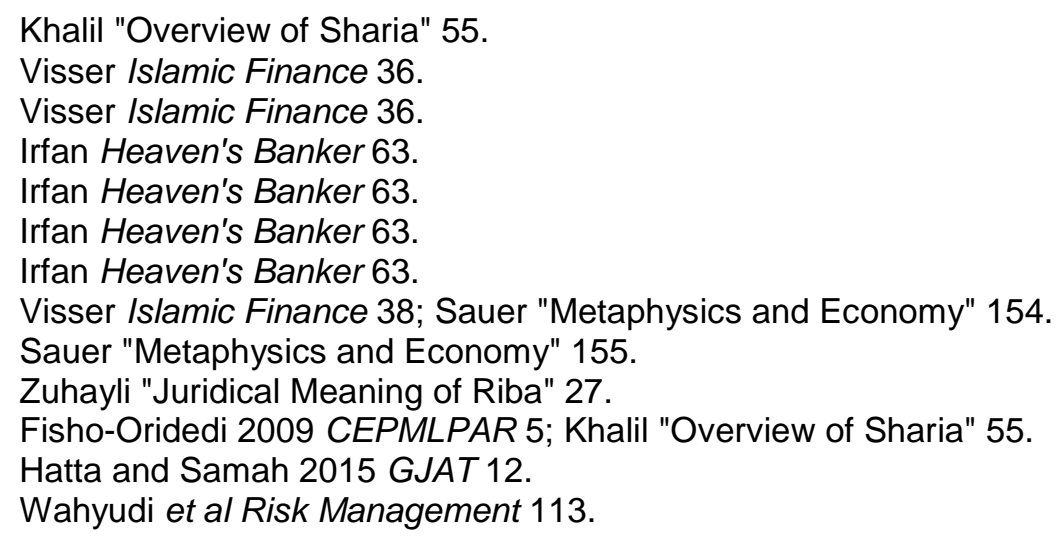


the actual loss suffered by the financier due to a delay in payment (ta'widh), as well as the penalty charges imposed for such a delay, without the need to prove the actual loss (gharamah). ${ }^{38}$ Such penalties can be charged, provided that the money is given to charity and is not income for the creditor. ${ }^{39}$

\subsection{Permissible financial products in terms of Sharia law}

If the financial system were based on adherence to the classical position and the prohibition against levying interest on loans, this would raise a simple question: how would lenders be able to yield positive returns from the capital amounts that they advanced, without contravening Islamic law? In particular, are there any halal alternatives to the charging of interest on loans? Islamic law provides few modes of financing which serve as a replacement for the prohibitions against riba-based financing. The bulk of these modes of financing derive from financial instruments that are "engineered" on the basis of the profit and loss sharing principle (PLS) and asset-based financing, which have become primary characteristics of Islamic banking. ${ }^{40}$ To understand what each of these financial instruments actually entails, one needs to understand the PLS principle upon which they are based.

\subsubsection{PLS-based Islamic financial instruments}

The PLS principle stems from the promotion of profit from trade and productive investments under the Sharia law. ${ }^{41}$ This principle generally means that the lender must share in the profits and losses arising out of the project for which the money was lent. ${ }^{42}$ What is objectionable in terms of the prohibition against riba, as previously indicated, is not the payment of profit, but a pre-determined rate of return that is not the result of the profits and losses incurred by either party to a financial transaction. ${ }^{43}$ This principle helps to draw a distinction between a prohibited riba and a legitimate return on investment. It recognises the use of an expected rate of return which is based on the risk that may arise from the operation of a financial transaction. ${ }^{44}$ To implement this principle and be Sharia compliant, some forms of financial arrangements have been developed which are consistent

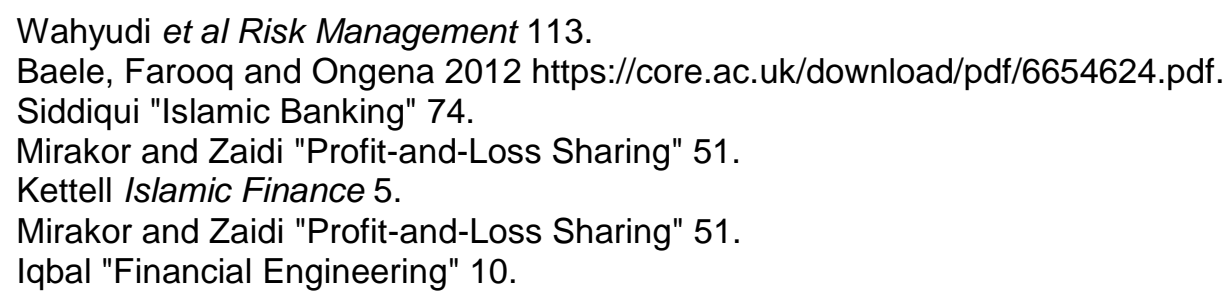


with encouraging trade and profit. What is evident from the literature is that all parties to a financial transaction need not share in both profit and loss. In certain transactions, one party (mostly the financier) may fully shoulder the risk of loss. ${ }^{45}$ As correctly stated, "[the] underlying idea is that Quran ... prohibits riba but applauds trade and profit, which is not frowned upon". ${ }^{46}$ As a result, there are numerous financial instruments that have been accepted as Sharia-compliant and which have become the core of Islamic finance today. The relevant permissible Islamic banking products are discussed below.

The most recognised equity-based Islamic financial instruments, based on the PLS principle, are the mudarabah (trust financing) and musharakah (partnership financing). ${ }^{47}$ Both are based on the idea of partnership: a passive partnership in the case of mudarabah and an active one in the case of musharakah. ${ }^{48}$ Mudarabah is defined as a type of partnership where one party - a financier or a bank - supplies the capital, while the other party provides the expertise, management and labour. ${ }^{49}$ It is called "trust financing" because the financier entrusts his or her finance or investment to another party. ${ }^{50}$ If the project results in profit, they share it in pre-determined proportions. If it results in a loss, the entire loss is borne solely by the financier, and the entrepreneur gains no benefit out of his or her effort. ${ }^{51}$ Musharakah, unlike mudarabah, is purely a partnership financial instrument. It refers to a partnership agreement between two or more parties, in which the partners contribute either capital or labour in order to carry out a joint venture. ${ }^{52}$ Unlike mudarabah, both parties contribute the capital and both have management rights in the project. ${ }^{53}$ In a musharakah, both parties share in the profit according to a pre-agreed formula. Losses, however, are shared strictly according to their respective contributions to the partnership. ${ }^{54}$ Although partnership based on the PLS principle is highly recommended under the Sharia law, it is not always easy to find partners to create a joint venture, in order to obtain financing.

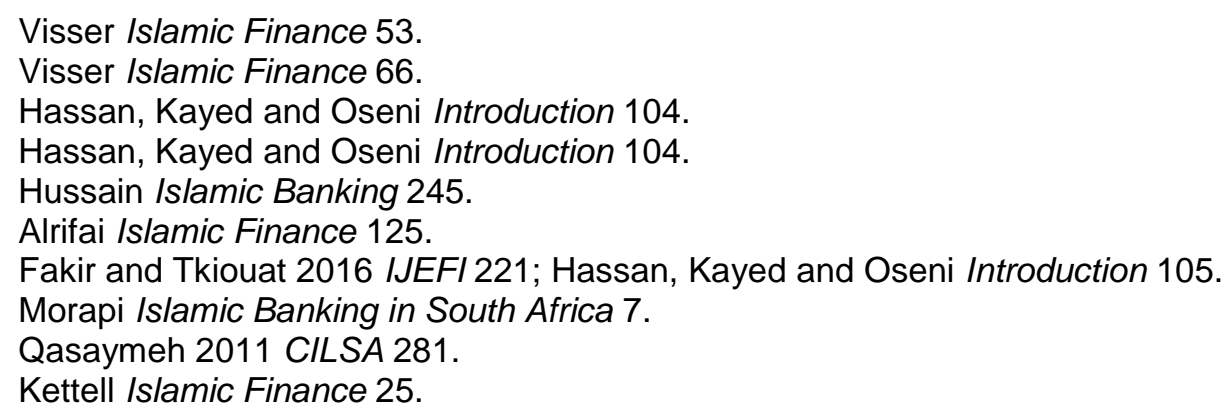


Islamic law also recognises another financing instrument called murabaha (cost plus). Murabaha is debt-like, asset-based financing, in terms of which a customer requests the financial institution to purchase an asset for him or her and then sells it to the customer at an agreed price. ${ }^{55} \mathrm{In}$ terms of this agreement, the financial institution buys a product or asset at the request of the buyer in the market at its own $\operatorname{coss}^{56}$ and for its own account. ${ }^{57}$ The financial institution takes legal possession of the asset and later sells it to the buyer at cost plus a mark-up. ${ }^{58}$ By taking possession of the financed property, the financial institution bears the risk during the period between purchasing the property and reselling it to the customer. ${ }^{59}$ One of the key features of murabaha, which distinguishes it from a conventional loan, is that one cannot receive cash as a subject of the agreement. ${ }^{60}$ In a murabaha transaction, the agreed sale price of the asset consists of the amount of financing and a predetermined profit margin. ${ }^{61}$ This mark-up profit is generally not regarded as interest, simply because the financial institution is not giving a loan to the customer, but selling the goods to the customer at a profit. ${ }^{62}$ At first glance, financing in terms of murabaha looks like a conventional loan, admitting the prohibited interest as cost plus profit through the back door. In support of this position, it is argued that the credit price charged by a financial institution, which includes a pre-specified profit margin, is parallel to a prohibited riba with similar characteristics to the one charged in conventional financing. ${ }^{63}$ The reason for its acceptability, however, is that it has an "asset-for-money" character rather than a prohibited "money-for-money" character. In terms of murabaha, the financial institution does not lend the borrower money and ask for the money over time plus a profit in addition to the loan capital. ${ }^{64}$ By buying the asset and then reselling it at a higher price, the financial institution takes a risk associated with the possibility of a sudden fall in price, which could see the buyer refusing to accept the asset at the agreed higher price. ${ }^{65} \mathrm{It}$ is acting as a seller rather than a moneylender. ${ }^{66}$ The additional profit is not associated with the lending of money but with the buying and selling of the

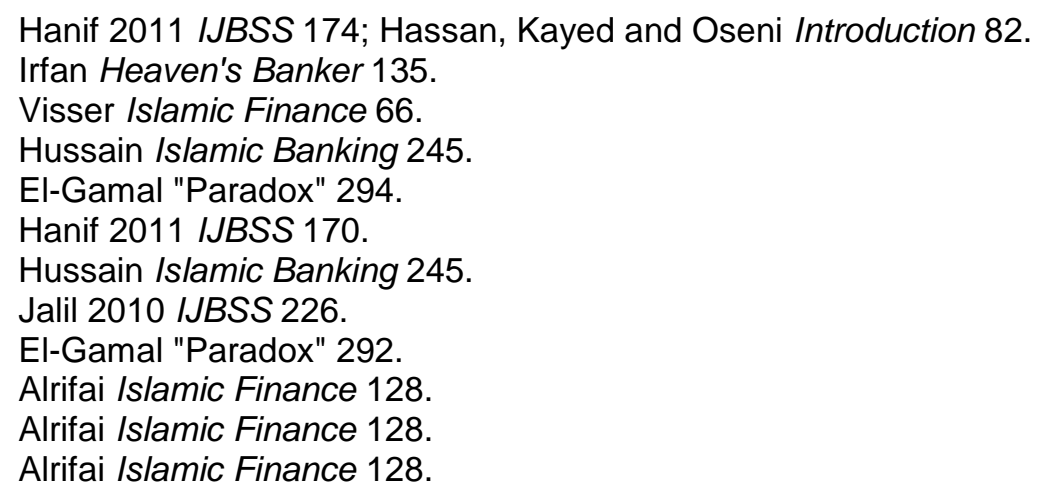


asset. ${ }^{67}$ The acquisition of assets is the key element of murabaha which distinguishes it from the normal consumption interest-based loan, which is prohibited under Sharia law. ${ }^{68}$

\subsubsection{Wakalah (agency) contracts as an ancillary to PLS contracts}

Each of the above financial products may be offered on its own or with others as hybrid products. One of the permissible contracts recognised as the most frequently accessed form of contract in all major Islamic financial agreements is known as wakalah (agency). Literally, wakalah means looking after, taking custody, or applying skill on behalf of others. ${ }^{69}$ Its operational models are twofold: they consist of pure wakalah and a combination of, for instance, mudarabah and wakalah. ${ }^{70}$ In a pure wakalah, the agent (wakil) is not entitled to a profit in a PLS contract, but to an agreed agency fee based on his or her duties. ${ }^{71}$ The principal (mutawakki) bears the risks associated with the transaction. Exceptions are those that arise from the agent's negligence or misconduct. ${ }^{72}$ In a combined mudarabah and wakalah, the agent is entitled to both an agent's fee for the efforts taken in managing the investment project, and to a share of the profit at an agreed ratio, once the investment has realised any such profit. ${ }^{73}$ In order to be Sharia compliant, the wakalah agreement must not involve any of the prohibited practices, including the prohibition against riba. Like other Islamic financial contracts, wakalah (pure or combined) may be used as a "legal device" (hilah, or hiyal in the plural) in order to achieve certain objectives through legal means. ${ }^{74}$ Although these objectives may be lawful or unlawful, hiyal are mostly used when it would be impossible to attain one's objective without violating the law. ${ }^{75}$ In most cases, these legal stratagems are used in Islamic financing to circumvent the prohibition against riba, in order to frustrate the objectives of Sharia law. ${ }^{76}$ For instance, parties may decide on a loan agreement without a predetermined interest so as to circumvent the prohibition against levying interest, by also entering into an agent agreement with the lender (as the agent), who is entitled to an excessive agency fee. The test for whether or not a particular legal device is lawful

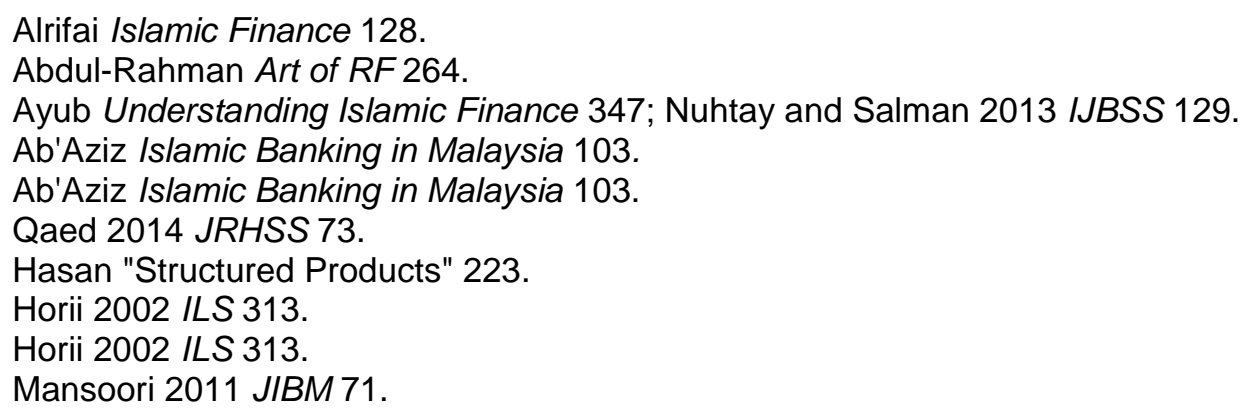


depends on whether or not the purpose of such a device is simply to overcome the rigidity and inconvenience of any prohibition in terms of the Islamic law. ${ }^{77}$ The motive of the parties thus determines the legality or illegality of the contract. ${ }^{78}$ The relevant question that must be asked in the context of Islamic banking and finance is "whether the legal device used amounts to a trick or deception in order to open a back door for prohibited riba". ${ }^{79}$ This note will now discuss the facts of the case and how the SCA dealt with these principles as they arose in the factual disputes between the parties.

\section{The facts in the Lodhi SCA case}

The facts in the Lodhi SCA case arose from a relationship between the first appellant, Lodhi 5 Properties Investment CC ("Lodhi 5"), and the respondent, FirstRand Bank Limited ("FirstRand"). Lodhi 5 is one entity within the Lodhi Group. Another entity within the group is Lodhi 4 Properties Investments (Pty) Ltd ("Lodhi 4"), the second appellant. The third appellant, Mr Lodhi, is the sole member of Lodhi 5, which conducts the business involving rare and fine art, sporting goods, auctioneering and textile industries. ${ }^{80}$ FirstRand offers to its Islamic customers specialised services and products that are compliant with Sharia law, in addition to its conventional banking products. ${ }^{81}$ One of the products offered to Islamic customers is called Islamic Finance Residential Property Offering. ${ }^{82}$ This involves an agency agreement that allows FirstRand to act as an agent when purchasing property on behalf of its customers in return for a fixed agency fee. ${ }^{83}$

In 2008 FirstRand loaned a sum of R9,6 million to Lodhi 5 in terms of an interest-free loan agreement. ${ }^{84}$ The amount was loaned for the purchase of two properties in Kramerville, Johannesburg. This agreement provided that the loan amount would be repayable in 120 monthly instalments of R88 000 . The parties also entered into an "Agency and Administration Service Agreement" in terms of which FirstRand acted as Lodhi 5's exclusive agent and purchased the property on the latter's behalf. ${ }^{85}$ In return, Lodhi 5 would

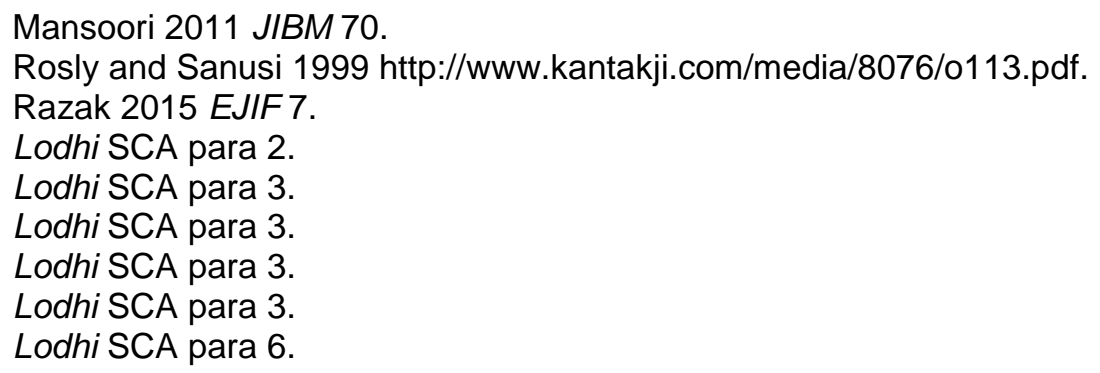


pay an additional $8 \%$ administration fee to FirstRand, which was also payable in 120 monthly instalments. ${ }^{86}$

As security for its indebtedness, Lodhi 4 and Mr Lodhi also executed a suretyship agreement in FirstRand's favour. In terms of this agreement, $\mathrm{Mr}$ Lodhi and Lodhi 4 would be liable to pay FirstRand all amounts owing in the event that Lodhi 5 was unable to perform its obligations under the loan agreement and agency agreement. ${ }^{87} \mathrm{~A}$ covering mortgage bond was also registered over one of the properties in favour of the bank. ${ }^{88}$ Lodhi 5 made regular payments in discharge of the loan until September $2009 .{ }^{89}$ It later made a payment of R5 million in May 2010 towards the discharge of the loan from the insurance pay-out resulting from a fire which destroyed the building purchased through the loan granted to Lodhi $5 .^{90}$ No further payments were made thereafter.

Following these defaults in payment, FirstRand sent letters of demand to the appellants between April and May 2011, requesting them to make payments within 21 days from the dates of these letters, failing which they would be placed in mora and deemed unable to pay their debts. ${ }^{91}$ Notwithstanding, none of the appellants responded to these letters. As a result, FirstRand launched an application in the $\mathrm{HC}$ to place Lodhi 5 and Lodhi 4 under final winding-up, and for Mr Lodhi to pay the outstanding amount on the loan. ${ }^{92}$ FirstRand relied on both the loan agreement and agency agreement alleging that Lodhi 5 had fallen into arrears in terms of both agreements. It alleged that the sums of R3 609 331, 52 and R6 773 242, 73 remained owing as capital in terms of the loan agreement, and the balance of administration fees in terms of the agency agreement, respectively. ${ }^{93}$

\section{$4 \quad$ The main issues}

\subsection{The issues and the decision in the High Court}

The parties approached the $\mathrm{HC}$ in three applications. ${ }^{94}$ The first two related applications involved placing Lodhi 4 and Lodhi 5 under final winding-up

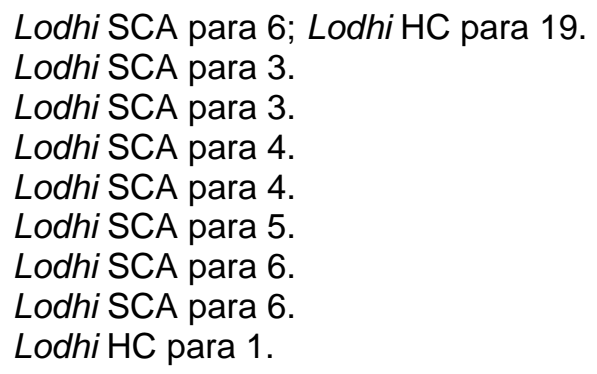


based on their actual and deemed inability to repay their debtors in terms of the provisions of the old Companies Act $^{95}$ and the Close Corporations Act. ${ }^{96}$ The court, per Molefe $\mathrm{J}$, approved these applications on the basis of the alleged failure by these companies to respond to the letters of demand and to make payments in terms thereof. It also looked at their financial statements and concluded that each company's annual income "equate[d] to just over one month's repayment in terms of the loan agreement", excluding the payment of operating expenses. ${ }^{97}$ This was sufficient proof that they were unable to pay their debts. ${ }^{98}$ The third application, which is important for the purpose of this discussion, relates to the money judgment against Mr Lodhi. In this regard FirstRand relied on the terms of the suretyship agreement. It argued that in the event that Lodhi 5 was placed under winding-up, Mr Lodhi would have no defence against FirstRand's claim and would be liable to make payment in terms of the suretyship agreement. ${ }^{99}$

The appellants did not deny the existence of a valid agency agreement. ${ }^{100}$ However, they denied that any of the fees stipulated in the agreement were due and payable. ${ }^{101}$ They raised several defences to support this position. Firstly, they invoked exceptio non adimpleti contractus and argued that FirstRand was not entitled to payment, as it did not render its own quid pro quo. ${ }^{102}$ In particular, they argued that FirstRand had rendered no performance to earn any agency fee. Secondly, and related to the first defence, they invoked an alleged suspensive condition which has the effect of bringing both the loan and the agency agreements into effect upon signature by all parties. ${ }^{103}$ They also alleged that a second offer to purchase had to be signed by the appellants and the seller in relation to the purchases of the two properties. ${ }^{104}$ As none of these conditions had been fulfilled, they argued that FirstRand was not entitled to any agency fee. ${ }^{105}$

The third defence is important and requires closer examination. According to the appellants, the "fees" claimed by FirstRand under the agency

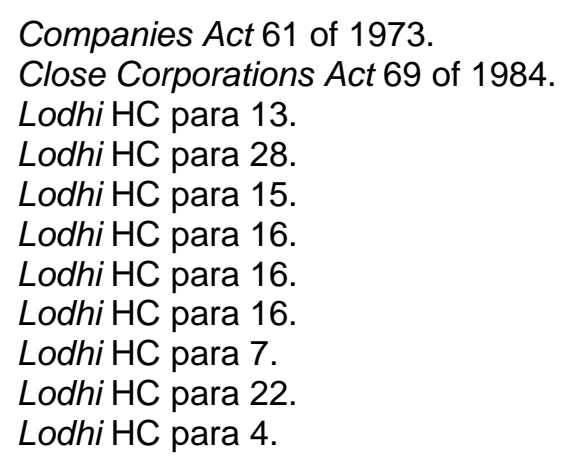


agreement were "nothing but 'riba'". ${ }^{106}$ As a result, the only amount due and payable was the outstanding capital amount in terms of the loan agreement. ${ }^{107}$ The argument with regard to the "riba" defence related to a clause in the loan agreement which provided that their transactions should be compliant with Sharia law, particularly the prohibition against the charging of interest. ${ }^{108}$ They argued that the agency agreement amounted to the charging of the prohibited riba, which rendered it illegitimate. The essence of the argument was that the whole transaction was not Shariacompliant. The defendants finally argued that FirstRand failed to meet its obligations in accordance with Sharia law, as the agreements were not explained to Mr Lodhi, but were based on the assumption that they would be entered into on the basis of the benefits of profit and risk sharing. ${ }^{109}$ The written agreements therefore conflicted with the understanding of Mr Lodhi's "intention of the loan transaction". ${ }^{110}$ For reasons that are discussed below, the appellants were unsuccessful in their defence, and therefore appealed to the SCA against both the winding-up and money judgment orders.

\subsection{The issues and the decision in the SCA}

The main issues on appeal were crystallised into the following questions: whether or not (a) Lodhi 4 and Lodhi 5 were correctly placed under windingup; (b) the appeal should succeed partially by the reduction of the amount owed by Mr Lodhi to the outstanding capital amount; and (c) Mr Lodhi was liable to pay interest on such an amount, and if so, from which date. The SCA upheld the HC's ruling on the winding-up question for the same reasons. The discussion will therefore focus on the other questions raised on appeal, as they are relevant to the defences raised in relation to compliance with Sharia law and the prohibition of riba.

\section{The decisions in the High Court and the SCA}

The main factual issue involved in this case was whether or not FirstRand was entitled to the restitution of the money advanced in terms of the loan agreement and, if so, whether or not the appellants were obliged to pay back the capital amount together with any additional amount. Secondly, whether or not it was entitled to any agency fee for the work done under the agency agreement. The issue whether or not any amount was due and

Lodhi HC para 16.

Lodhi $\mathrm{HC}$ para 16.

Lodhi $\mathrm{HC}$ para 19 and fn 10.

Lodhi $\mathrm{HC}$ para 20.

Lodhi HC para 21. 
payable depended on whether or not the court upheld any of the defences raised by the appellants. In both the $\mathrm{HC}$ and the SCA the courts agreed on the winding-up of Lodhi 4 and Lodhi $5 .{ }^{111}$ Both courts also ordered Mr Lodhi to pay FirstRand the money that was due and payable, together with interest. ${ }^{112}$ However, for reasons that are discussed below, the courts differed on the amounts and reasons for such payments. They also differed in terms of the reasons whether or not these transactions were Sharia compliant.

In order to address the question regarding the reduction of the loan amount and the possible liability for interest, the SCA (as had the HC) had also to address the question as to whether or not the debt claimed was due and payable. The appellants did not deny that a certain amount of the capital sum remained owing under these contracts. Their main contention was that FirstRand had not accelerated the repayment of instalments in terms of the loan agreement. ${ }^{113}$ Secondly, they argued that the payment of R5 million from the insurance proceeds amounted to the prepayment of 62 instalments and a year's worth of instalments in advance. Put differently, they were arguing that the payment made from the insurance effectively paid the monthly instalments for many months to come. Therefore, the full amount was not outstanding at the time of the application. Both the $\mathrm{HC}$ and the SCA disagreed with the argument pertaining to the acceleration of repayment. Both agreed with the bank's submission that a written notice by FirstRand to the applicants did actually reserve the right to declare all or part of the capital outstanding to be immediately due and payable and was therefore sufficient to accelerate the payment. ${ }^{114}$ As the $\mathrm{HC}$ correctly held, the "notice did declare that the outstanding balance is due and payable". ${ }^{115}$ The only right reserved, the court further held, "was to declare whether part or all the capital outstanding is due and payable". ${ }^{116}$ That is, once the letter of demand served to accelerate the payment, it was left to each party to raise the issue as to how much was immediately payable.

Having decided that the amount was due and payable, the $\mathrm{HC}$ had to decide how much was payable. In this regard, it had to decide whether the money payable was only the outstanding capital amount or whether interest on that amount was payable and, if so, from which date. The applicants relied on

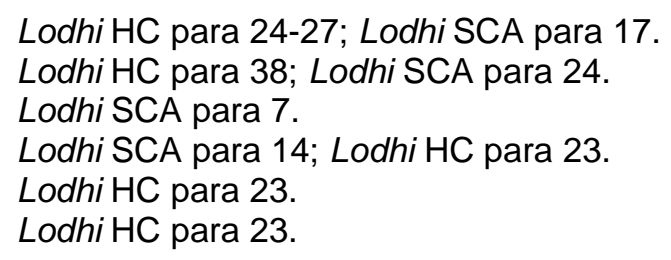


the following defence in this regard. They argued that FirstRand had failed to meet its obligation in terms of Sharia law because neither of the agreements had been explained to Mr Lodhi. As a result, he entered into these agreements with the understanding that they would be based on the sharing of profit, as well as any risk arising from the transactions. ${ }^{117}$ Their position was basically that both agreements were generally void for noncompliance with Sharia law. They argued that the bank was not entitled to any interest as the agency fee "amounted to interest in breach of Shari'ah law". ${ }^{118}$ Both the HC and the SCA dealt with this issue, but the $\mathrm{HC}$ analysed the applicable principles in more detail than the SCA. It dealt both with the issue of Sharia compliance and the issue of the interest that was payable. The HC looked at the fact that Mr Lodhi implemented all the transactions and accepted the benefits (of purchasing the house with the loan money and the extinguishing of existing debts). ${ }^{119}$ It also took into account the personality of Mr Lodhi as "an astute businessman". ${ }^{120}$ It further questioned Mr Lodhi's failure to explain why he knowingly, and applying Islamic principles, read and signed the agreements without any protest "if they were not Sharia compliant with his religious beliefs". ${ }^{121}$ It therefore found his defence to be far-fetched and untenable. ${ }^{122}$ This issue was not brought on appeal to the SCA as the parties limited their appeal to the questions of the winding-up and the amount payable. ${ }^{123}$

With regard to the amount that FirstRand was reclaiming, the $\mathrm{HC}$ and the SCA approached this issue differently. Having discussed some of the forms of financial transaction which are Sharia-compliant (such as wakalah), the $\mathrm{HC}$ analysed whether or not the loan agreement was Sharia-compliant. ${ }^{124}$ It approached the matter by asking whether or not the loan transaction provided for a shared responsibility for profit and loss between the borrower and the lender. ${ }^{125}$ After analysing both the loan and agency transactions, the $\mathrm{HC}$ concluded that the loan agreement between the parties was not a profit-sharing agreement. ${ }^{126}$ Its reason was that "[t]he only party benefiting from this transaction was the respondents" (as they were in the lower

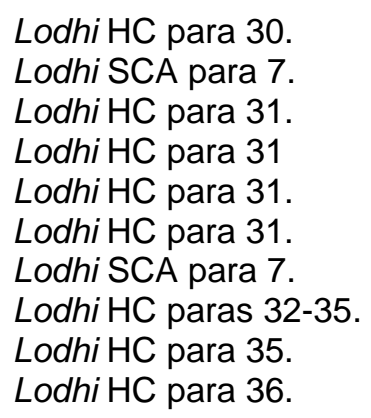


court). ${ }^{127}$ It concluded that the transaction was a residential property offered with a fixed agency fee. ${ }^{128}$ As a result it held, rather surprisingly, that the loan and agency agreements were Sharia-compliant. ${ }^{129}$ It ordered Mr Lodhi to repay FirstRand a cumulative amount of R10 328574,25 plus interest on the said amount, at the rate of $15.5 \%$ per annum calculated from the 18 April until date of the payment. ${ }^{130}$

The SCA also arrived at a similar decision. It ordered Mr Lodhi to repay FirstRand an amount of R2 642 006.95, together with interest thereon at the rate of $15.5 \%$ per annum from 15 June 2012 to the date of the appeal. ${ }^{131}$ The SCA agreed with FirstRand's position that Mr Lodhi was liable for interest on the reduced sum at the legal rate of $15.5 \%$ at the material time. The SCA approached this issue by questioning the nature or the type of interest charged in terms of the agreements between the parties. ${ }^{132}$ It held that the interest sought by FirstRand was not based on the enforcement of a contractual undertaking. ${ }^{133}$ In the court's view, this interest was based on Lodhi's default in payment. ${ }^{134}$ It reasoned that the interest was mora interest intended to compensate the party who suffered a loss as a result of "being deprived of the use of the capital for a period of time". ${ }^{135}$ According to the SCA, the interest constituted damage that flowed naturally from the contract itself, due to a failure to perform a contractual obligation within the agreed time. ${ }^{136}$ In the SCA's view, this obligation had "nothing to do with and is not affected by the Sharia law's prohibition against payment of interest on a loan debt". ${ }^{137}$ It therefore found Mr Lodhi liable to compensate FirstRand for its failure to perform by the due date at a legal rate of interest as prescribed by section 1(2) of the Prescribed Rates of Interest Act. ${ }^{138}$

\section{Critical analysis}

The decision in Lodhi 5 SCA thought to illustrate an eagerness in our courts to adjudicate on matters relating to Islamic law. Islamic banking law is

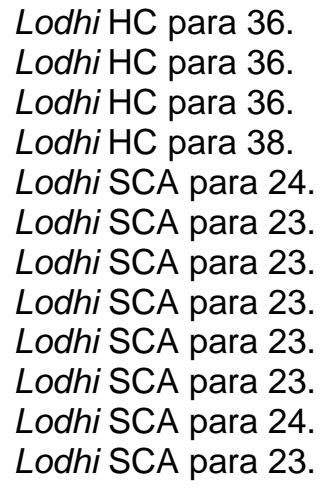


already part of South African law. ${ }^{139}$ The law has, however, yet to be given detailed explication by our courts. This poses a question as to whether our courts, which are grounded in the common law, are willing to adopt and apply the principles of Islamic banking in South African law. The HC in this case has, to a minimal extent, reached its decision by infusing some principles of Islamic banking law into its deliberations. However, it still left unanswered many relevant questions arising from the facts. The parties in this case had agreed that the agreement between them would be governed by Sharia law but they had failed to agree on the specific principles of Sharia law applicable to their agreement. As a result, there were questions that were left for judicial interpretation by the courts.

The first question that the SCA had to address was whether FirstRand was entitled to charge interest in addition to the capital. It is apparent that the parties intended that the agreement should be governed by Sharia law. As the SCA correctly approached the matter, it had to decide on whether or not these transactions were Sharia compliant. This raised the question as to whether or not FirstRand was entitled to anything more than the loan capital in terms of Sharia law. This question pertains to what Sharia law actually permits. The SCA (like the HC) was reluctant to attempt to interpret what the prohibition against riba entails. The HC's dismissal of the appellant's claim was based on its acceptance that Mr Lodhi implemented the entire transaction and accepted the benefits without any protest. ${ }^{140}$ The court in this regard was able to expose the scope of possible abuses by defaulting debtors, who use the argument of the invalidity of Islamic law to avoid making payments in terms of transactions governed by this law. However, the HC's position that a financial transaction is permissible under Sharia law only if all parties share in the profit and loss in terms of the PLS principle is questionable. As indicated earlier, in certain transactions, loss can be borne fully by only one party. ${ }^{141}$ This principle does not entail that profit always be shared among the parties. It simply requires that a financial transaction should have the sharing of profit and loss as its main aim. As a result, the sharing of profit and loss is not in itself the end, but only the means to a Sharia-compliant transaction. With respect, the $\mathrm{HC}$ erred by applying the PLS principle as a precondition for compliance with Sharia law. Despite holding that the parties did not share in the profit and loss in terms of the

139 Albaraka Bank Ltd v Halaal Royal Snacks (Pty) Ltd (SGHC) unreported case number $08400 / 2010$ para 4, Mudarabah and other Islamic finance products are now incorporated into the Income Tax Act 58 of 1962 in terms of the Taxation Laws Amendment Act 24 of 2011.

140 Lodhi HC para 31.

141 See para 4.2.1 above. 
loan agreement, the $\mathrm{HC}$ further concluded, surprisingly, that the loan and agency agreements were Sharia-compliant. The question that remains is how these agreements can be thought to be Sharia-compliant if, in the court's view, all parties do not share in the profit and loss.

Likewise, the SCA avoided addressing the main issue before it, which was whether or not Sharia law applied to the transactions. It also did not deal with the question as to whether an additional amount claimed constituted a prohibited riba. Arguably, this was a question that required the Court to take the position of either the classical school or the contemporary Muslim school in this regard. Taking the former position would have led to the conclusion that FirstRand was entitled to the advanced capital amount only. The respondent would have been liable for only the outstanding capital amount advanced by the bank. Even taking the contemporary Muslim scholars' approach would not yield a different result. FirstRand did not, as the SCA concluded, claim interest based on the enforcement of a contractual undertaking. ${ }^{142}$ The interest claimed was not in the nature of interest agreed upon in a contract, but the claim was based on the default of payment by a debtor. If the claim had been based on the enforcement of a contractual undertaking, the position of contemporary scholars would have been relevant. The court would be called upon to decide whether or not the chaff could be separated from the grain: in other words, whether or not an acceptable amount of additional profit could be separated from the prohibited exorbitant interest. Instead, the court decided the matter by looking at the nature of the interest claimed. It is submitted that the SCA ignored the parties' intention to subject their agreement to Sharia law.

Another question that the SCA left unanswered was whether or not the charging of mora interest in transactions subject to Sharia law is enforceable in South African law. The SCA's view was that the liability of the debtor to compensate the creditor for failure to perform on the due date "has nothing to do with and is not affected by the Sharia law's prohibition against payment of interest on a loan debt". ${ }^{143}$ While the rights under common law cannot be denied by the application of Islamic law principles, the defence regarding riba was purely on the basis that Sharia law governed the agreement between the parties. Payment of this interest had to be decided in terms of what Sharia law permits. When applying Sharia law, the bank's claim for default interest in this case could not be regarded as either tawhid or gharamah. There is no indication that the claim for default interest would not

142 Lodhi SCA para 23.

143 Lodhi SCA para 23. 
constitute an additional income to FirstRand, nor is there any indication that the money would be given to charity, as suggested by contemporary Islamic scholars. Therefore the SCA's focus on attempting to establish the type of interest in question was totally unrelated to the parties' intention that the agreement should be governed by Sharia law.

Having decided on the nature of the interest claimed under the loan agreement, the SCA further failed to address the question as to whether or not the fees under the agency agreement constituted riba, as claimed. This failure denied the parties an opportunity to address their dispute on this point. In order to rule on this question, the court would first have had to address the defence of exceptio non adimpleti contractus. If successful, this defence would allow the appellants to withhold the payment of agency fees until FirstRand had performed in terms of the agency agreement. This defence, however, would still not hold any ground, as FirstRand actually purchased the properties on behalf of the respondents, who subsequently registered a mortgage bond over the properties. ${ }^{144}$ If it were accepted that there was a quid pro quo on behalf of FirstRand, it would have had to be determined whether or not the payment of the claimed agency fees would have constituted riba. This would have been purely a matter of interpretation of the Islamic law. The charging of agency fees is accepted by both classical and modern Muslim scholars, as already indicated. ${ }^{145}$ Unless the use of loan and agency agreements (as hybrid murabaha and wakalah) in this case could be regarded as hilah to circumvent the strict prohibition against riba under the loan agreement, by charging agency fees in terms of the agency agreement, FirstRand would be entitled to the agency fees once it was established that it had rendered performance in terms of this agreement. In this regard, the appellants would have needed to prove only that the agency agreement was intended to achieve an unlawful objective under the loan agreement, with the intention of circumventing the prohibition against riba. In the absence of this proof, the $\mathrm{HC}$ and the SCA were therefore correct in concluding that the agency agreement was Sharia-compliant, notwithstanding their failure to analyse the relevant principles in this regard. The agency fee was payable, as FirstRand has performed by buying the property on behalf of the appellants.

The SCA's conclusion that the respondents' obligation to pay default interest had nothing to do with and was not affected by Sharia law's prohibition against the payment of interest also left much to be desired with regard to

\footnotetext{
144 Lodhi SCA para 3.

145 See para 4.1 above. Also see Kusheni and Hayat Contracts and Deals 11.
} 
the enforceability of Islamic law by our common law courts. This problem exists mostly in those jurisdictions in which the legal systems are secular, such as the United Kingdom. Common law is still dominant, as judicial officers lack the necessary expertise to address disputes arising in terms of the enforcement of Sharia law. ${ }^{146}$ As a result, the courts adopt a dismissive approach to the parties' choice of Sharia law as the governing law for their transactions. Expert views on Islamic law are often ignored in favour of the application of the national law. ${ }^{147}$ Contractual disputes are resolved by applying the law of the country in question, disregarding the intention of the parties and the commercial goals of Islamic finance law. ${ }^{148}$

In the UK, for instance, leading cases ${ }^{149}$ involving murabaha agreements between the financial institutions and their customers provided for a choice of English law or "the principles of the Glorious Sharia" as the governing law. In these cases the UK courts accepted English law as the governing law and therefore ignored the intention of the parties to subject their agreement to Sharia principles. The attitude of English courts towards the enforcement of Islamic banking law is exemplified by Potter ${ }^{150}$ as follow:

It was improbable in the extreme, that the parties were truly asking the English court to get into the matters of Islamic religion and orthodoxy.

The court further characterised the reference to Sharia law as being simply a reference to Islamic religious principles for conducting banking business, rather than to a system of law which could trump the application of English law. ${ }^{151}$ In justifying its stance, the court relied heavily on the existence of controversy arising from the existence of various schools of thought regarding the application of Islamic law. ${ }^{152}$ Controversial as the approach of the UK courts is, they have made their standpoint on the enforcement of Sharia law quite clear: English law trumps Sharia law in conflict of law matters. The position in South Africa, however, remains unclear. The approach by the $\mathrm{HC}$ seems to hold out a "jurisprudential promise" of

146 Ginena and Hamid Foundations 104.

147 Yaacob 2011 http://ifikr.isra.my/documents/10180/16168/19.pdf 5.

148 Beximco Pharmaceuticals Ltd v Shamil Bank of Bahrain EC 2004 APP LR 01/28.

149 Islamic Investment Company of Gulf (Bahamas) Ltd v Symphony Gems NV 2002 WL 346969 (QB Comm Ct 13 February 2002); Beximco Pharmaceuticals Ltd v Shamil Bank of Bahrain EC 2004 APP LR 01/28; The Investment Dar Company KSCC v Blom Developments Bank SAL 2009 EWHC 3545 (Ch).

150 Beximco Pharmaceuticals Ltd $v$ Shamil Bank of Bahrain EC 2004 APP LR 01/28 para 41.

151 Beximco Pharmaceuticals Ltd v Shamil Bank of Bahrain EC 2004 APP LR 01/28 para 54.

152 Beximco Pharmaceuticals Ltd v Shamil Bank of Bahrain EC 2004 APP LR 01/28 para 54. 
interpreting and enforcing Islamic law. Its pronouncement about the requirements of a PLS principle is an indication that the court is willing to entertain disputes relating to the enforcement of financial transactions governed by Islamic law. However, the decision of the SCA flies in the face of this approach. To reiterate, the judicial officers in Lodhi SCA were arguably called upon to enforce the agreements between the parties in accordance with Islamic law, as the parties intended. However, the SCA chose to address the main question as to whether or not the agreements involved a prohibited riba outside the scope of the governing clause of the loan agreement between the parties by asking whether or not default interest was payable due to the loss, which is "compensated by an award of mora interest". ${ }^{153}$ The SCA was implicitly adopting the English approach of applying the common law applicable to banking law in South Africa, instead of the Islamic law chosen by the parties. Unlike the English courts, the $\mathrm{HC}$ and the SCA did not call for experts on Sharia law to advise on the possible solution to this dispute. As the Malaysian Appeal Court correctly pronounced:

... judges in civil court[s] should not take upon themselves to declare whether the matter is in accordance to the Religion of Islam or otherwise as it needs consideration by eminent jurists who are properly qualified in the field of Islamic jurisprudence. ${ }^{154}$

Unless such matters can be referred to available specialised forums, they definitely calls for the opinion of experts who could provide insight into the Islamic principles at play in such cases. One should, however, acknowledge that there are differences in matters of the interpretation of Islamic law amongst Sharia experts. Civil courts should nevertheless be able to take into account different views and opinions and have the power to make a final determination on such matters. Their views are important when they adjudicate on issues that require the interpretation of Islamic law. The SCA in this case should have invited experts in Sharia law to assist with the adjudication of the issues before it. Had the SCA based its decision on the governing law in terms of the agreement between the parties, it would not have been necessary to conclude that Mr Lodhi was liable for default interest. Its failure to apply or pronounce on its position regarding the enforcement and interpretation of the governing law clause in this case leaves open the question as to whether or not parties to financial agreements governed by Islamic law can rely on the courts for the resolution of their disputes. This question that will remain open until another similar

\footnotetext{
153 Lodhi SCA para 23.

154 Bank Islam Malaysia Berhad v Lim Kok Hoe 20096 MLJ 839840.
} 
issue comes before our courts, and they are willing to guide us on the enforceability of Islamic banking law. The SCA's reluctance to entertain this question also leaves open other questions regarding the contents of the agreements by the parties in terms of Islamic law. These questions include the following: what the ambit of the riba prohibitions is (the question of whether the chaff can be separated from the grain); whether or not hybrid loan and agency agreements are simply unlawful legal devices (hiyal) meant to circumvent the strictness of Sharia law; and whether or not the Islamic Finance Residential Property Offering (as provided to the appellants in this case) as well as agency fees charged in terms of an agency agreement are Sharia-compliant under South African law.

\section{Conclusion}

The decision in Lodhi 5 SCA provides some lessons to both parties entering into transactions incorporating Sharia law as the governing law, as well as to judicial officers regarding the challenges in terms of enforcing this law. To the former, a simple lesson is the reluctance of our secular courts to accept the application of Islamic finance principles. This reluctance creates challenges with regard to which forum is capable of addressing disputes arising from transactions based on Islamic finance principles. This reluctance is evident in this case, as the court did not address the dispute between the parties in terms of their choice of law. What is evident in this judgement is that the court had no knowledge of what the principles of Sharia law are. The SCA's failure to invite experts in Sharia law to provide guidance on the applicable Islamic law remains a cause for concern, particularly in terms of whether or not parties can in future expect our courts to enforce agreements based on Islamic law. As already indicated, the court failed to take a stand on whether or not it might enforce Islamic law. It could also not address several questions that were posed to it such as the content of a riba prohibition, and whether or not agency fees in terms of wakala agreements as well as the use of hybrid contracts of murabaha and wakala (as in this case) are Sharia-compliant. These questions will remain unanswered until another similar case comes before our courts.

South African courts need to clearly indicate whether or not they are willing to enforce and apply Islamic finance law as the governing law of a particular transaction. 


\section{Bibliography}

\section{Literature}

Ab'Aziz Islamic Banking in Malaysia

Ab'Aziz MR Islamic Banking and Finance in Malaysia; System, Issues and Challenges (USIM Negeri Sembilan 2013)

Abdul-Rahman Art of RF

Abdul-Rahman Y The Art of RF (Riba-Free) Islamic Banking and Finance: Tools and Techniques for Community-Based Banking $2^{\text {nd }}$ ed (Wiley Hoboken 2014)

Ali Holy Qur'ān: Translation

Ali MS The Holy Qur'ān: Arabic Text and English Translation (Islamic International Publications Islamabad 2004)

Alrifai Islamic Finance

Alrifai T Islamic Finance and the New Financial System: An Ethical Approach to Preventing Future Financial Crises (Wiley Singapore 2015)

Ayub Understanding Islamic Finance

Ayub M Understanding Islamic Finance (Wiley London 2007)

Chapra $1984 \mathrm{HI}$

Chapra MU "The Nature of Riba in Islam" 1984 HI 3-24

El-Gamal "Paradox"

El-Gamal MA "Interest and the Paradox of Contemporary Islamic Law and Finance" in Al-Roubaie A and Alvi S (eds) Islamic Banking and Finance: Critical Concepts in Economics - Vol II (Routledge London 2010) 281-308

Fakir and Tkiouat 2016 IJEFI

Fakir AEL and Tkiouat M "Single or Menu Contracting: An Application of the Hersanyi Model to Mudaraba Financing" 2016 IJEFI 221-230

Fisho-Oridedi 2009 CEPMLPAR

Fisho-Oridedi A "The Prohibition of Riba under the Islamic Law: What are the Implications for the International Contracts" 2009 CEPMLPAR 1-20

Garner 2013 LJLC

Garner JM "A Critical Perspective on the Principles of Islamic Finance Focusing on Sharia Compliance and Arbitrage" 2013 LJLC 69-90 
Ginena and Hamid Foundations

Ginena K and Hamid A Foundations of Shari'ah Governance of Islamic Banks (Wiley Chichester 2015)

Hanif 2011 IJBSS

Hanif M "Difference and Similarities in Islamic and Conventional Banking" 2011 IJBSS 166-175

Hasan "Structured Products"

Hasan A "Islamic Structured Products: Issues and Challenges" in Vernandos AM (ed) Current Issues in Islamic Banking and Finance: Resilience and Stability in the Present System (World Scientific Singapore 2010) 189-227

Hassan, Kayed and Oseni Introduction

Hassan MK, Kayed RN and Oseni UA Introduction to Islamic Banking and Finance: Principles and Practice (Pearson Harlow 2013)

Hatta and Samah 2015 GJAT

Hatta $\mathrm{M}$ and Samah S "Compensation and Penalty Imposed on Debt Settlement of Islamic Products" 2015 GJAT 7-18

Horii 2002 ILS

Horii $S$ "Reconsideration of the Legal Devices (Hiyal) in Islamic Jurisprudence: The Hanafīs and Their Exits (Makhārij)" 2002 ILS 312-357

Hussain Islamic Banking

Hussain MG Islamic Banking and Finance: Status and Issues (Deep and Deep New Delhi 2011)

lqbal "Financial Engineering"

lqbal Z "Financial Engineering in Islamic Finance" in Al-Roubaie A and Alvi S (eds) Islamic Banking and Finance: Critical Concepts in Economics - Vol /I (Routledge London 2010) 7-21

Irfan Heaven's Banker

Irfan H Heaven's Banker: Inside the Hidden World of Islamic Finance (Constable London 2014)

Jalil 2010 IJBSS

Jalil MA "Financial Transactions in Islamic Banking are Viable Alternative to the Conventional Banking Transactions" 2010 IJBSS 219-233 
Kettell Islamic Finance

Kettell B Islamic Finance in a Nutshell: A Guide for Non-specialists (Wiley Chichester 2010)

Khalil "Overview of Sharia"

Khalil E "An Overview of the Sharia'ah Prohibition of Riba" in Thomas A (ed) Interest in Islamic Economics: Understanding Riba (Routledge London 2006) $55-68$

Kusheni and Hayat Contracts and Deals

Kusheni $\mathrm{H}$ and Hayat $\mathrm{M}$ Contracts and Deals in Islamic Finance: $A$ User Guide to Cash Flows, Balance Sheets, and Capital Structures (Wiley Singapore 2015)

Mansoori 2011 JIBM

Mansoori MT "Use of Hiyal in Islamic Finance and its Sharīah Legitimacy" 2011 JIBM 69-92

Mirakor and Zaidi "Profit-and-Loss Sharing"

Mirakor A and Zaidi I "Profit-and-loss Sharing Contracts in Islamic Finance" in Hassan MK and Lewis MK (eds) Handbook of Islamic Banking (Elgar Cornwall 2007) 49-63

Morapi Islamic Banking in South Africa

Morapi LThe Regulation of Islamic Banking and Financial Institutions in South Africa (LLM-dissertation University of Johannesburg 2014)

Nuhtay and Salman 2013 IJBSS

Nuhtay SN and Salman SA "Shari'ah and Ethical Issues in the Practice of Modified Wakalah Model in Family Takaful" 2013 IJBSS 128-132

Okon 2012 AJSMS

Okon EE "The Sources and Schools of Islamic Jurisprudence" 2012 AJSMS 106-111

Qaed 2014 JRHSS

Qaed IQM "The Concept of Wadiah and its Application in Islamic Banking" 2014 JRHSS 70-74

Qasaymeh 2011 CILSA

Qasaymeh K "Islamic Banking in South Africa: Between the Accumulation of Wealth and the Promotion of Social Prosperity" 2011 CILSA 275-292 
Razak 2015 EJIF

Razak AHA "The Fundamentals of Islamic Banking and Finance: Apologue" 2015 EJIF 1-11

Saeed Islamic Banking

Saeed A Islamic Banking and Interest: A Study of the Prohibition of Riba and its Contemporary Interpretation (Brill Leiden 1996)

Sauer "Metaphysics and Economy"

Sauer JB "Metaphysics and Economy - The Problem of Interest: A Comparison of the Practice and Ethics of Interest in Islamic and Christian Cultures" in Al-Roubaie A and Alvi S (eds) Islamic Banking and Finance: Critical Concepts in Economics - Vol II (Routledge London 2010) 153-174

Sharawy 2001 GJICL

Sharawy HM "Understanding the Islamic Prohibition of Interest: A Guide to Aid Economic Cooperation between the Islamic and Western Worlds" 2001 GJICL 153-179

Siddiqui "Islamic Banking"

Siddiqui S "Islamic Banking: Rationale, Prospects and Challenges" in AlRoubaie A and Alvi S (eds) Islamic Banking and Finance: Critical Concepts in Economics - Vol IV (Routledge London 2010) 73-89

Swartz 2012 AJBM

Swartz N "The Prevention of Over-indebtedness: The Problem of Interest and the Islamic Response" 2012 AJBM 10099-10108

Thomas "What is Riba"

Thomas A "What is Riba" in Al-Roubaie A and Alvi S (eds) Islamic Banking and Finance: Critical Concepts in Economics - Vol II (Routledge London 2010) 133-142

Visser Islamic Finance

Visser H Islamic Finance: Principles and Practice $2^{\text {nd }}$ ed (Edward Elgar Cheltenham 2013)

Wahyudi et al Risk Management

Wahyudi I et al Risk Management for Islamic Banks: Recent Developments from Asia and the Middle East (Wiley Singapore 2015) 
Zuhayli "Juridical Meaning of Riba"

Zuhayli S "The Juridical Meaning of Riba" in Thomas A (ed) Interest in Islamic Economics: Understanding Riba (Routledge London 2006) 26-54

Case law

Malaysia

Bank Islam Malaysia Berhad v Lim Kok Hoe 20096 MLJ 839

\section{South Africa}

Albaraka Bank Ltd v Halaal Royal Snacks (Pty) Ltd (SGHC) unreported case number 08400/2010

FirstRand Bank Ltd v Lodhi 5 Properties Investment CC 20133 SA 212 (GNP)

Lodhi 5 Properties Investments CC v First Rand Bank Limited 20153 All SA 32 (SCA)

\section{United Kingdom}

Beximco Pharmaceuticals Ltd $v$ Shamil Bank of Bahrain EC 2004 APP LR $01 / 28$

Islamic Investment Company of Gulf (Bahamas) Ltd v Symphony Gems NV 2002 WL 346969 (QB Comm Ct 13 February 2002)

The Investment Dar Company KSCC v Blom Developments Bank SAL 2009 EWHC 3545 (Ch)

\section{Legislation}

Close Corporations Act 69 of 1984

Companies Act 61 of 1973

Income Tax Act 58 of 1962

Prescribed Rates of Interest Act 55 of 1975

Tax Law Amendment Act 24 of 2011 


\section{Internet sources}

Ali 1987 http://www.streathammosque.org/uploads/quran/english-quranyusuf-ali.pdf

Ali AY 1987 The Holy Qur'ān: English Translation of the Meanings http://www.streathammosque.org/uploads/quran/english-quran-yusufali.pdf accessed 17 May 2016

Baele, Farooq and Ongena 2012 https://core.ac.uk/ download/pdf/6654624.pdf

Baele L, Farooq M and Ongena S 2012 Of Religion and Redemption: Evidence from Default on Islamic Loans https://core.ac.uk/download/pdf/ 6654624.pdf accessed 17 May 2016

Rosly and Sanusi 1999 http://www.kantakji.com/media/8076/o113.pdf Rosly SA and Sanusi MM 1999 The Application of Bay'AL-'Inah and Bay' Al-Dayn in Malaysian Islamic Bonds: An Islamic Analysis http://www.kantakji.com/media/8076/o113.pdf accessed 17 May 2016

Yaacob 2011 http://ifikr.isra.my/documents/10180/16168/19.pdf Yaacob H 2011 A Critical Appraisal of International Islamic Finances Cases, and the Way Forward http://ifikr.isra.my/documents/10180/16168/19.pdf accessed 19 May 2016

\section{LIST OF ABBREVIATIONS}

AJBM

AJSMS

CEPMLPAR

CILSA

EJIF

GJAT

GJICL

$\mathrm{HC}$

$\mathrm{HI}$

IJBSS
African Journal of Business Management American Journal of Social and Management Sciences

The Centre for Energy, Petroleum and Mineral Law and Policy Annual Review Comparative and International Law Journal of South Africa

European Journal of Islamic Finance Global Journal Al-Thaqafah

Georgia Journal of International and Comparative Law

High Court

Hamdard Islamus

International Journal of Business and Social Science 


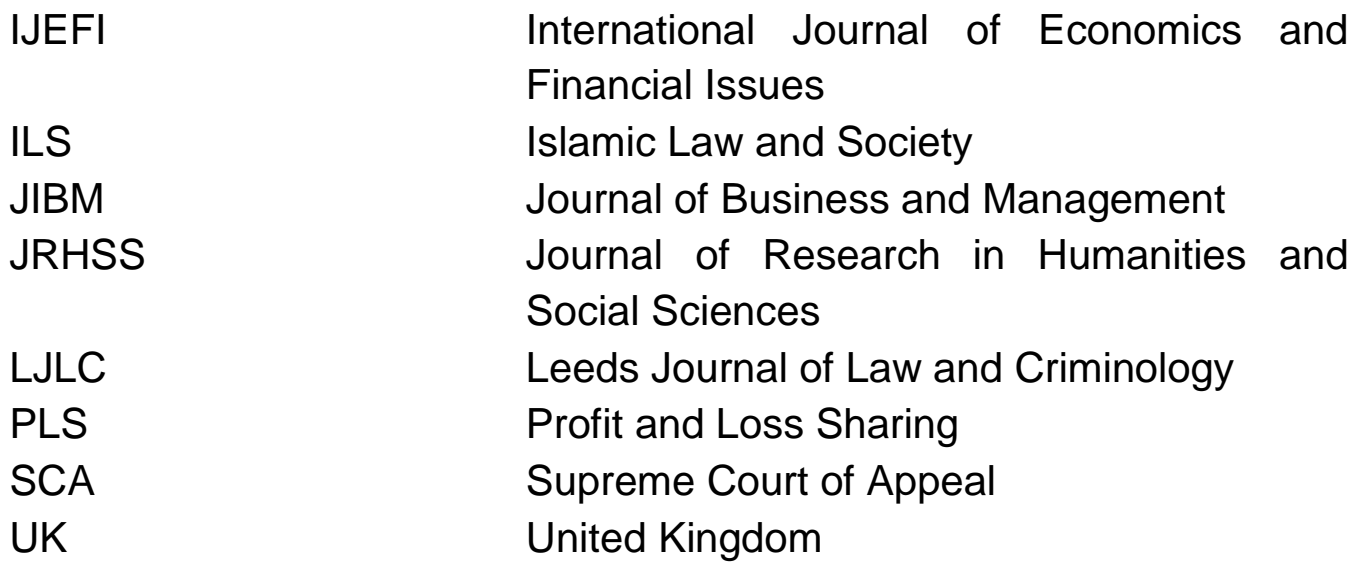

